\title{
Reconciling Conflicting Interests of Coastal and Riparian States: The Hard Case of Black Sea Straits
}

\author{
Jetta Abgaryan \\ Russian-Armenian Slavonic University, Armenia \\ jetta.ab@gmail.com \\ George Chakhvadze \\ Ivane Javakhishvili Tbilisi State University, Georgia \\ george.chakhvadze@yahoo.com \\ Levan Jakeli \\ Batumi Shota Rustaveli State University, Georgia \\ l.jakeli@bsu.edu.ge \\ Dr. iur. Jānis Grasis \\ ORCID: 0000-0002-1394-9958 \\ Rìga Stradiñš University, Faculty of Law, Latvia \\ janis.grasis@rsu.lv
}

\begin{abstract}
There are two basic understandings of the regime of the Black Sea straits: the Black Sea straits as a legal regime and the Black Sea straits as a political regime [1]. The legal assessment of the Black Sea Straits regime requires determining what the existing regulation of the Straits is, how open the Straits are to international navigation, and if closed, whether there are real legal grounds for closing straits while the reference to the Black Sea Straits as a political regime allows for the possibility that straits may be closed for ensuring the security of Turkey and the Black Sea riparian states [1].

It is worth noting that arguments advanced by international legal scientists on the Black Sea straits as legal regime fundamentally differ from each other. Some scientists consider the Montreux Convention to be a major problem in the legal regulation of the Black Sea straits. They consider it necessary for Turkey to recognise the 1982 Convention on the Law of the Sea as a legally binding treaty [2]. Others argue that the main problem in regulating the Black Sea straits is the unilateral regulations adopted
\end{abstract}


Jetta Abgaryan, George Chakhvadze, Levan Jakeli, Jānis Grasis. Reconciling Conflicting Interests of Coastal and Riparian States: The Hard Case of Black Sea Straits

by Turkey (1994, 1998 and 2003 Regulations), which, in their view, violate the basic norms of the Montreux Convention, especially the regime of free passage through the straits established by this Convention [3; 4]. Another group of scientists believes that although the regime of the Black Sea straits is significantly restricted by Turkish unilateral regulations, these acts are aimed at protecting the marine environment and safety, and, therefore, the Turkish policy of regulating the Black Sea Straits is legally justified $[1 ; 5]$.

This article is dedicated to the international legal regulation of navigation in the Black Sea Straits. The aim of the paper is to evaluate the current regime of the Black Sea Straits, the relationship and differences between the regime established by the Montreux Convention and the unilateral acts adopted by Turkey on the regulation of traffic in the Black Sea Straits, and to answer the question whether the urgent need to protect the natural environment and maritime safety entitles Turkey to restrict the regime established by the Montreux Convention. Thus, special attention will be drawn to the Montreux Convention, the rules and recommendations adopted by the International Maritime Organisation and the case law of international courts. In the view of the authors, the environmental and safety arguments put forward by Turkey for restricting navigation through the Black Sea Straits have two conceptual dimensions. First, these arguments are acceptable when it comes either to introducing norms related to the movement of ships to ensure safety of navigation or providing an obligation of notification to the Turkish authorities [6]. Another important thesis advanced by this article is that in each particular case, the regulations adopted by Turkey should be interpreted in the light of the recommendations made by the International Maritime Organisation. The main rationale of this argument is that under the existing regulations, Turkish authorities can still suspend the movement of ships in the straits for various reasons, some of which are quite vague. However, the article showcases that Turkey can, in case of pressing environmental need, when there is an urgent interest in the protection of the natural environment, act with the motive of protecting the natural environment, regardless of whether this action derives from a particular international treaty.

Keywords: Black Sea Straits, legal regulation, Montreux Convention.

\section{Introduction}

It should be noted that Turkey is not a party to the 1982 Convention on the Law of the Sea (hereinafter referred to as the 1982 Convention). Passage through the Black Sea Straits is regulated by the 1936 Montreux Convention [7]. Turkey recognises the special role of the Montreux Convention in regulating navigation through the Black Sea straits and ensuring stability in the region. The regime established by this convention has been stable for decades, but since the 1990s Turkey has unilaterally changed the rules. In particular, after a major accident in the Bosphorus Strait in 1994, which caused an explosion and fire, the Turkish government adopted regulations to change the rules of navigation 
Jetta Abgaryan, George Chakhvadze, Levan Jakeli, Jānis Grasis. Reconciling Conflicting Interests of Coastal and Riparian States: The Hard Case of Black Sea Straits

in the Black Sea Straits. This was followed by the 1998 Regulations, which replaced the 1994 Regulations, as well as the 2003 Regulations on the Movement of Ships through the Turkish Straits $[6 ; 8 ; 9]$.

\section{Opinion on Legality of Turkish Unilateral Acts}

Objectively, the new Turkish regulations were a big step forward towards avoiding pollution in these straits, improving movement of ships and ensuring safety of navigation, but as some scholars point out, these regulations have very problematic provisions that violate the basic principles of the Montreux Convention concerning the navigation through the Black Sea Straits [4].

As professor Martin Belsky points out, the international community rarely agrees to the unilateral action of a single government if that action affects the rights of the international community [10]. Moreover, the scholars point out that the unilateral change of regulation in the straits used for international shipping is already contrary to the fundamental principle of international maritime law on unimpeded transit and the foundations of public international law. They argue that the existence of an international treaty in the form of the Montreux Convention, which regulates the legal regime of navigation in the Black Sea Straits, suggests that the subject matter of the legal regulation is international and not a domestic one. Consequently, the state interests of Turkey should not be justified by illegal actions. It is not surprising that a number of the Black Sea states, especially Russia, strongly oppose the regulations adopted by Turkey, arguing that the right of their ships to cross the Black Sea Straits is violated. In addition to Russia, these states include Ukraine, Romania, Bulgaria, Greece and Cyprus. These states are also protesting against the great economic damage caused by the delay of ships in the Black Sea Straits and are rejecting environmental arguments invoked by the Turkish government. For instance, the spokesman for the Greek Ministry of Maritime Trade Tracivolus Stavridopoulos called the Turkish government's environmental argument a bluff based on Turkey's political and economic aspirations [2]. One can say that the harsh criticism of the Greek side regarding Turkish regulations has some support in legal scholarship as well. For example, Christopher Joyner and Jeanne Mitchell argue that although the interest in protecting the Black Sea natural environment is unequivocal, Turkey still cannot re-evaluate its friendly relations with the Black Sea states for economic and strategic reasons [3].

The environmental and safety arguments put forward by Turkey in terms of restricting access to the Straits are quite reasoned (this line is also developed in the present paper); simultaneously, it must be emphasised that Turkey, as the only state bordering the Black Sea Straits, the sole determinant of the regime of the Black Sea Straits, should take into account the interests of the riparian states. In this regard, the interests of Georgia as the Black sea riparian state should also be taken into account as the Black Sea straits are the only exit for Georgia to the world ocean. 
Jetta Abgaryan, George Chakhvadze, Levan Jakeli, Jānis Grasis. Reconciling Conflicting Interests of Coastal and Riparian States: The Hard Case of Black Sea Straits

The existence of an international treaty in the form of the Montreux Convention, which regulates the legal regime of navigation through the Black Sea Straits, indicates that the subject of legal regulation is international and not a domestic one. Such case indicates that environmental considerations of the coastal state should not be justified by illegal actions. In its resolutions, the UN General Assembly also calls on the coastal and riparian states to work together to ensure the safety of navigation as well as to prevent, reduce and control pollution from ships [11].

In addition, the recommendations of the International Maritime Organisation show that despite the organisation's open position that the rules adopted by this organisation are not intended to affect the rights of any ship to use international straits under international law, including the 1982 Convention, the Montreux Convention of 1936 and the Turkish internal regulations, the organisation itself has recognised the need to deviate from the internal regulations adopted by Turkey to protect the interests of the states using the Black Sea Straits in exceptional cases [5].

Against the background of differences of opinion on the issue, the aim of the article remains to objectively assess the existing framework for the regulation of the Turkish Straits. The paper aims to determine the extent the regime established by the Montreux Convention is restricted and whether Turkey has had the right to adopt domestic acts regulating the Black Sea Straits.

In the authors' point of view, the environmental and safety arguments put forward by Turkey for restricting navigation in the Black Sea Straits have two conceptual dimensions. First, these arguments are acceptable when it comes either to introducing norms related to movement of ships to ensure safety of navigation or providing an obligation of notification to the Turkish authorities. A salient example of such a regulation is the establishment of a system of maritime traffic schemes adopted in accordance with Rule 10 of the International Convention for the Prevention of Collisions at Sea (COLREG 72) and approved by the Assembly of the International Maritime Organisation in 1995. The same can be said of other important articles of the 1998 Regulations. For example, Rule 13 of these regulations stipulates that ships should not exceed 10 knots while sailing. It is generally forbidden to overtake another ship, and any ship intending to overtake a low-speed vessel must obtain a permit from the Turkish Traffic Control Station.

Another important circumstance on the basis of which Turkey can restrict the principle of free passage established by the Montreux Convention is an urgent, pressing need to protect the natural environment. In this case, Turkey can act with the motive of protecting the natural environment regardless of whether its action derives from an international treaty. The sinking of the Liberian oil tanker Torrey Cannyon in 1967 on the west coast of Cornwall, the largest cargo ship ever to sink, could set another precedent when the state could act in an emergency to protect the natural environment whether or not the action derives from an international treaty [13]. The International Law Commission concluded that the bombing of the ship by British 
Jetta Abgaryan, George Chakhvadze, Levan Jakeli, Jānis Grasis. Reconciling Conflicting Interests of Coastal and Riparian States: The Hard Case of Black Sea Straits

forces was lawful because its ultimate aim was to prevent a massive oil spill on the coast of Britain, and this measure was taken only after all attempts to stop the pollution of the sea had ceased.

Notwithstanding the above, it is worthwhile to acknowledge that Turkey, as the only country bordering the Black Sea Straits, appears to be the sole determinant of the navigation regime in these Straits, and the interests of the states bordering the Straits may not be taken into account. In this regard, the interests of Georgia as a riparian state of the Black Sea should be considered, as the Black Sea straits are the only exit for Georgia to the world ocean; for example, the case of 2008 when Turkey did not allow an American warship to cross the Dardanelles Strait and enter the Black Sea. In particular, the US warship was going to enter Georgian territorial waters but because it had a capacity of more than 300 thousand tons, according to Turkish state regulations, a request to cross the strait had to be sent a few days in advance to consider a specific request and authorise the passage through the Strait. As this requirement was not met, the American ship could not enter the territory of Georgia. This decision of the Turkish state was difficult for Georgia, which was involved in the war with Russia at the time. It seems that Turkey to some extent has considered Russia's political interests when making such decision.

\section{Conclusion}

The ability of states to establish their own rules in straits enables them to regulate and control maritime traffic in these straits. This can significantly change the political and economic situation in some countries where maritime traffic depends on these straits.

Analysis of the Turkish unilateral regulations shows that to some extent they violate the norms of international public law. While the State bordering the Strait has the right to introduce additional rules to ensure safety and protection of the natural environment in the straits, this possibility must be realised in conformity with the interests of international navigation. Under current regulations, the Turkish government can hamper navigation in the straits, and this is justified by the fact that these measures are aimed at safety of navigation or other reasons. There are norms in the Turkish law that complicate the application of the Montreux Convention. For example, in 1982, the Turkish government tried to unilaterally expand the internal regime of the port of Istanbul to the Black Sea straits, which would allow Turkey to close these straits even in peace situation. Turkey rejected the idea only after a sharp criticism and pressure from the Black Sea riparian states. 
Jetta Abgaryan, George Chakhvadze, Levan Jakeli, Jānis Grasis. Reconciling Conflicting Interests of Coastal and Riparian States: The Hard Case of Black Sea Straits

\section{Bibliography}

1. Inan, Y. (2001). The current regime of the Turkish straits. Journal of International Affairs, 6 (1), p. 162.

2. Palvyuk, S. (1998). Regulation of the Turkish straits: UNCLOS as an alternative to the treaty of Montreaux and the 1994 Maritime Traffic Regulations for the Turkish straits and Marmara region. Fordham International Law Journal, 22 (961), p. 964.

3. Joyner, C. (2002). Regulating navigation through the Turkish straits: a challenge for the modern international environmental law. The International Journal of Marine and Coastal Law, 17 (4), p. 525.

4. Dremliuga, R. (2015). The development of the Black sea straits regulation of international navigation. Asian Social Science Journal, 11 (12), p. 269.

5. Fornari, M. (2005). Conflicting interests in the Turkish Straits: is the free passage of merchant vessels still applicable? The International Journal of Marine and Coastal Law, Volume 20: Issue 2, p. 225-246.

6. Maritime Traffic Regulations for the Turkish Straits and the Maramara Region. (1998). Available: http://www.vda.org.tr/upload/duyuru/T\%C3\%9CRK\% 20 BO\%C4\%9EAZLARI\%20DEN\%C4\%B0Z\%20TRAF\%C4\%B0K\%20D\%C3\%9CZEN\%C4\%B0\%20 Y\%C3\%96NETMEL\%C4\%B0\%C4\%9E\%C4\%B0\%20\%C4\%B0NG\%C4\%B0L\%C4\%B0ZCE\%202019.pdf [09.09.2020].

7. Convention Regarding the Regime of the Straits. (1936). Available: http://sam.baskent.edu.tr/ belge/Montreux_ENG.pdf [09.09.2020].

8. Maritime Traffic Regulations for the Turkish Straits and the Marmara Region. (1994). Available: https://www.un.org/Depts/los/LEGISLATIONANDTREATIES/PDFFILES/TUR_1994_ Regulations.pdf [09.09.2020].

9. Regulations on the Turkish Straits Vessel Traffic Service. (2003). Available: https://www.afcan. org/dossiers_techniques/tsvts_gb.html [09.09.2020].

10. Belsky, M. (1996). Using Legal Principles to Promote the "Health" of an Ecosystem". TuLsAJ. COMP. \& INT'L L 1, 2.

11. Resolution adopted by the General Assembly on 23 December 2016. 71/257. Oceans and the Law of the Sea. Available: https://www.un.org/en/development/desa/population/migration/generalassembly/docs/globalcompact/A_RES_71_257.pdf [10.09.2020].

12. Convention on the International Regulations for Preventing Collisions at Sea, 1972 (COLREGs). Available: https://www.imo.org/en/About/Conventions/Pages/COLREG.aspx [10.09.2020].

13. Torrey Canyon: The world's first major oil tanker disaster. Available: https://safety4sea.com/ cm-torrey-canyon-the-worlds-first-major-oil-tanker-disaster/ [10.09.2020]. 